\title{
Business Process Reengineering Resources and the Performance of Quoted Brewing Firms in Nigeria
}

\author{
Akam, G. U. ${ }^{\circledR}$ \\ Okeke, M. N. ${ }^{2}$ \\ Kekeocha, M. E. ${ }^{3}$ \\ Onuorah, A. N. ${ }^{4}$
}

${ }^{1,2, s, 4}$ Department of Business Administration Chukwuemeka Odumegwu University, Igbeariam Campus, Nigeria

\begin{abstract}
The study examined the effect of Business Process Reengineering (BPR) resources on the performance of brewing firms in Nigeria. Following the Kassahun (2012) BPR perspectives, the study grouped BPR resources into financial, human and technological resources. A sample of 746 employees was randomly selected from a population of 3500 from five brewing firms quoted in the Nigerian stock exchange. The Likert-type instrument of five-point scale used for data collection has a Cronbach alpha coefficient of 0.85 . The percentage frequency was used to examine the baseline information of BPR variables in brewing firms in Nigeria while OLS regression model analysed the effect of BPR on the performance of brewing firms in Nigeria. The study results showed that financial and technological resources were in adequate usage while human resources were moderate. Also, the performance of brewing firms in Nigeria at present is scored high in the five-point rating. The regression result indicated that BPR resources have $94 \%$ significant effect on the performance in brewing firms in Nigeria. Specifically, a positive influence was established such that financial resources $(63 \%)$ has more influence, followed by human resources $(20 \%)$ and then technological $(19 \%)$. This implies that the use of resources is a veritable strategy to enhancing firm performance. Firms that follow the present wave of technological innovations will enhance their competiveness and survival rate. The study therefore concluded that BPR is a veritable tool to enhancing employee satisfaction, team work and cooperation, quality of service delivery as well as attainment of organizational strategic goals in brewing firms in Nigeria. The study however, recommended that firms in the brewing industry and other allied manufacturing firms should employ its resources in an adequately proportionate manner.
\end{abstract}

Keywords: Business process, Business process reengineering, BPR critical success factors, Organisational performance.

\section{Introduction}

Several definitions suggest that Business Process Reengineering (BPR) is an offshoot of Business Process. BPR has frequently been used since it was first introduced in the United States in the 1990s. The concept of BPR was first used in Hammer's article 'Reengineering Work: Don't Automate, Obliterate' (Hammer 1990) as cited in Adeyemi and Aremu (2008). The concept of BPR aims at enabling organisations improve productivity and relationships with customers, and reduce time to launch new products and services in terms of cost, quality, customer satisfaction and shareholders' value by identifying and reengineering the important processes of the firm (Sentanin et al., 2008). It is a way in which organisations become more functional by identifying the critical business processes, analysing these processes and redesigning them for efficient improvement and benefit.

Technological innovations have brought about globalisation that exposes all businesses to customers with refined needs and preferences. These have engendered new market conditions characterized by instability and intense competition in the business environment (Hesson, 2007; Banham, 2010). Hence firms need to adopt a business approach that would help them cope with business trends especially in the face of high cost of doing business. Business managers thus have to rethink of new and better ways of doing businesses that will reduce cost and maximize profit (Ogbo et al., 2015).

The process of BPR connotes that firms must revamp their process, by engaging in radical redesign of core business processes to achieve dramatic improvements in productivity, cycle times and quality (Rigby, 2015). This means that to reengineer a business process implies starting with a blank sheet of paper and rethinking on an existing process to deliver more value to the customer. As a matter of ideal procedure, business process reengineering entails that organisations adopt a new value system that places more emphasis on customer needs. In the view of Zigiaris (2000) "BPR assumes that the current processes in a business are inapplicable and suggest completely new processes to be implemented by starting over". With this viewpoint, the designers of business processes are enabled to disassociate themselves from today's process, while focusing on a new process. In business process reengineering lies that propensity that organizations can perform in a better way, satisfy the customers and the employees, and enhance the quality of their products (Nadeem and Ahmad, 2016). 
However, for an organisation to engage in BPR, it must have an operating transactional and accounting computerized system; a network that connects all key personnel; workstations with Windows NT or Windows 1995 system or latest version; and an exchange server (MS outlook, or MS back office or Lotus Notes) (Zigiaris, 2000). Changing the entire business operations to conform to IT enabling business environment entails huge resource commitment. Resources involved in Business Process Reengineering projects include intensive financial resources for BPR-associated IT investment, staff retraining, organisational restructuring and BPR consultants (Willcocks, 2002; Ahadi, 2004; Ahmad et al., 2007).

As the world becomes technologically advanced, with increased global competition, the Nigerian brewing industry is left with no choice but to look beyond local competitors. Competition is intensifying in terms of price, quality of service; selection and promptness of delivery (see Idris (2011)). Thus, organisations have sought for means to reduce cost and improve business efficiency and effectiveness. All these aim to satisfy consumers, as consumer retention becomes a key factor in determining the success of any organisation. In this sense, a good number of organisations, including the brewing firms in Nigeria, have adopted business process reengineering as a management tool that can revamp their business process and make them more competitive.

The need to meet up with global standards and business competiveness has kept the firms in Nigerian brewing industry to think of ways and means to level up competition and remain in business. Despite the recent ventures to provide empirical evidences of the relationship between BPR implementation and organisational performance in Nigeria (see (Ringim et al., 2012; Ogbo et al., 2015)) no study in Nigeria has explained the effect of the huge resource input needed to implement the BPR project. The present study is anchored on the Kassahun (2012) BPRresources perspective to provide empirical evidence for BPR projects in Nigerian brewing firms.

\section{Literature Review}

\subsection{Conceptual Framework}

Sharma (2006) posits that business process reengineering implies transformed processes that together form a component of a larger system aimed at enabling organization to empower themselves with contemporary technologies, business solution and innovations. The most important factor for implementing BPR is the enabling role of Information Technology (Zigiaris, 2000). In a logical sense, businesses are organized around departments. This creates physical barriers in the communication of the various departments. For instance, where the warehouse is in another location, it will not be possible for a cross-functional team to communicate efficiently. Thus, accounting and production departments will experience delays in communicating thereby either making the customer to move from one department to another or have to wait until his transaction is communicated. With an automation of the business process, one department can communicate another so early without bothering the customer. This creates a one-stop service. Employees can easily operate as a team using intranets/extranets, workflow and groupware applications, eliminating distances. Business Process Reengineering makes it possible that employees can work together even though they are located in different places.

Rigby (2015) notes that business process reengineering involves reduced organizational layers and elimination of unproductive activities in two key areas. Firstly, a redesign of functional organizations into cross-functional teams, and the use of technology to improve data dissemination and decision making. Given the discontinuous nature of Business Process Reengineering (that is, a project at a point in time), there is need for a continuous improvement extension of the project that allows the Business Process Reengineering undertaking to take advantage of both the discontinuous radical and the continuous incremental process improvement undertakings (Weerakkody et al., 2011).

According to Zigiaris (2000) as soon as an organisation has undergone a complete Business Process Reengineering, the outcomes expected of the organisation, will include the following, several jobs are combined into one; decision-making becomes part of the job of employees (employee empowerment); steps in the processes are performed in a natural order, and several jobs get done simultaneously; processes have multiple versions. This enables the economies of scale that result from mass production, yet allows customization of products and services; work is performed where it makes the most sense; controls and checks and other non-value-added work are minimized; reconciliation is minimized by cutting back the number of external contact points and by creating business alliances; a single point of contact is provided to customers, and a hybrid centralized/decentralized operation is used.

In this study, organizational performances implies the performance of brewing firms quoted in the Nigerian Stock Exchange (NSE) in terms of both financial and non-financial performance indicators. Efficiency and effectiveness are the key terms for measuring the organizational performance (Mouzas, 2006). Kassahun (2012) asserts that effectiveness is the achieved outcomes in relation to strategic goals/objectives and customer requirement; while efficiency connotes how economically the organisation's resources are utilised by an activity such as a business process that produces a given output or delivers a given service. Organisational effectiveness and efficiency can be measured by financial and non-financial indicators. This study considered that the non-financial performance indicators such as customer satisfaction, market share, learning and innovation, customer service management, market research, customer relationship management, new service/product introduction, product/service quality, flexibility, operational performance, speed, process improvement and service/product delivery (Ringim et al., 2012). Non-financial measures cover both the value that is delivered to the customer which may involve time, quality, performance and service, and the outcomes that arise as a result of this value proposition, such as customer satisfaction and market share.

\subsection{Theoretical Review}

The study hinges on the Resource-Based View (RBV) Theory which holds that organization are rent seeking units that develops and deploy resources (assets and capabilities) to realize competitive advantage. This follows that for organisations to gain competitive advantage over others, they should hold better resources than their competitors. Since Resource-Based View emphasises that an organization's ability can be developed and deployed to its internal resources, business process reengineering becomes a veritable tool for restructuring both an 
organisation and the process therein in a manner that becomes less time and money consuming. As the core essence of business is to meet its goals including satisfying consumers at a profit, the Resource-Based View (RBV) becomes relevant to this study. This is because for an organisation to become competitive, it has to periodically redesign and restructure its processes to meet current business and consumer orientations, all these tasks demand resources. Therefore, availability of resources is a prerequisite to business process reengineering.

\subsection{Theoretical Exposition}

The resource perspective of BPR attributes BPR's effect on performance to the type and size of the financial, technological and human resources employed in the execution of Business Process Reengineering project. Studies have noted that Business Process Reengineering projects involve an intensive financial resources for BPRassociated IT investment, staff retraining, organisational restructuring and BPR consultants (Willcocks, 2002; Ahadi, 2004; Ahmad et al., 2007). By this notion, it appears that lack of the necessary financial resources for carrying out corporate business plan leads to failure of Business Process Reengineering projects. Also a cause of failure of BPR as a financial resource is the use of personnel and managers that do not have the requisite expertise on the processes to be redesigned, as well as cross-functional knowledge and know-how in handling a BPR project (Sung and Gibson, 1998; Do Carmo et al., 2005). Also paramount to the success of Business Process Reengineering projects are the knowledge and skill of the BPR team on change management, BPR project management and IT infrastructure resources (Khong and Richardson, 2003). The acquisition of these skills enhances customer service performance, which in turn has a positive effect on business performance. Thus a successful Business Process Reengineering projects should put into consideration financial, human and technological resources that are necessary for project execution. Thus, the availability and effective utilisation of scarce resources can determine the extent of BPR's effect on the performance of brewing firms.

In the case of technological resources necessary for the BPR projects, researchers posit that the type of IT investment and its extent of utilisation in the reengineered business process are more important than the size of investment (Devaraj and Kohli, 2000; Willcocks, 2002; Albadvi et al., 2007). This suggests that firms preparing for BPR should acquire the requisite technological resources

Successful BPR implementation in organisations hinges on organisation's BPR capacity in distinguishing value-adding missions and service delivery processes from non-value adding ones. These capacities of the knowledge of the BPR processes, implementation capability and familiarity with change management, are human capacities. Macintosh (2003) asserts that financial capacity is more important for BPR project success.

Other authors describe these capacities as BPR team competencies which in their view include knowledge and skill regarding the organisational functional process, BPR and BPR methodologies, change management, role of IT in BPR and BPR project management. These are seen as critical for organisational BPR project success (Thong et al., 2000; McAdam and Corrigan, 2001; Scholl, 2005). Hence, it becomes necessary for firms to emphasise retention of the reengineering team until completion, as the reengineering team's competence is pertinent in change management, the role of IT in BPR and those functions of the organisation to be redesigned; empowering employees; and continuously monitoring and improving the BPR outcome (Thong et al., 2000).

In a similar vein, Ongaro (2004) reports that BPR implementation indicates that deployment of sufficient resources and use of competent reengineering team are sine qua non to successful implementation of BPR projects and enhanced organisational performance. This supports the theoretical proposition that availability of resources is the requisite demand to engender increased organisational performance from implementation of BPR projects. On this note, the Resource Based View (RBV) becomes central to conceptualising the link of organisation's resources, knowledge, and business process performance to organisational performance (Dzhumalieva and Helfert, 2008). Thus, the use of RBV to investigate the organisational value of BPR is theoretically sound.

\subsection{Empirical Studies}

Empirical studies have been conducted on BPR resources and organisational performance. Among the studies are Ahadi (2004) which employed BPR critical success factors to survey 72 companies in automotive and electronics industry in Iran to determine the effect of BPR resources on organisational performance. It adopted the hierarchical regression techniques in data analyses and that resources, top management support, change management, centralisation of decision making and formalisation of procedures have positive associations with BPR success.

In another study, Ahmad et al. (2007) conducted a case study of three private higher education institutions in Malaysia to investigate the critical success factors in higher education that drive Business process reengineering and found that deployment of adequate resources and BPR teams with knowledge and skill on IT/IS, change management and project management contribute to BPR project success. In a similar vein, Albadvi et al. (2007) used a face-to-face paper-based survey design to assess the impact of IT and BPR on performance using 200 managers of car manufacturing firms in Iran and posited that the type of IT diffused and the extent of business process change has a strong and positive effect on perceived organisational performance.

In a longitudinal study, Devaraj and Kohli (2000) noted that radical change to enable organization's IT and IS requires organisations to have both financial capacity.

They employed a case study of eight (8) hospitals in US to examine the effect of financial resources on the success of Business Process Reengineering. With the size and type of BPR expenditure as the explanatory variables of Business process reengineering, and impact measures as the proxy for organisational performance. The study found that ccombined effect of process change and IT investment has strong and positive effect on performance.

Do Carmo et al. (2005) carried out a survey among 192 hospital administrators in US to determine hospital BPR success. The study considered the functional and BPR project management knowledge and skill of the BPR team, and the top management's commitment and support as important measurement indicators, alongside investment in IT. The dependent variables of the study include cross-functionality of the project team, BPR methodology, IT and leadership. The study found a positive relationship between level of BPR personnel 
knowledge and skill and improved service quality, reduction in cost, reduction in cycle time, profitability and customer and staff satisfaction.

In Nigeria, Ogbo et al. (2015) looked at business process reengineering and the performance of commercial banks in north central Nigeria. A sample size of 501 was drawn from a population of 7977 in 12 selected commercial banks in middle-belt, Nigeria. Survey design method was used and data were collected using questionnaire and structured interview. The analysis of data interpretation yielded the following findings: Speed enhanced the profitability of commercial banks in north central Nigeria to a great extent; there was a significant positive relationship between corporate restructuring and competitive advantage; appropriate level of process knowledge and effective process reorientation were the critical success factors for a successful business process reengineering exercise in the banking sector in north central Nigeria. In conclusion, banks that are adopting business process re-engineering have different success level. Individual organization's success depends on established balance between organization structure and organization's environment.

Explored the effect of BPR on performance of courier service firms in Anambra State of Nigeria. The BPR factors comprising Change Management, Less bureaucratic structure (flatter structure), Management Commitment, Process Redesign, and infrastructure (IT) were regressed against organizational performance. The study employed descriptive research design. Data were obtained using 18 item Likert-scale type questionnaire structured into Strongly agree (SA), Agree (A), Neutral (N), Disagree (D), and Strongly Disagree (SD). The data were analysed using Principal Component Analysis and Multiple Regression Analysis. The result of the analysis revealed that there was a significant relationship between BPR factors (change management, process redesign, management commitment, and IT infrastructure) and overall organisational performance of the selected Courier Service Organisations. Based on the finding, the study concluded that BPR is a vital model for improvement in firms' operational performance and achievement of long term growth and competitive advantage.

Anchored on Business Action theory, Orogbu et al. (2015) sought to find out the extent to which work process innovation influences employee retention and then examined the level of relationship between process redesign and employee satisfaction. The study adopted a descriptive survey design on a sample size of one hundred and twelve (112) persons from the population of 887 using random sampling and complete enumeration method. Pearson's product moment correlation and $\mathrm{Z}$ test were used to test the significance of the coefficient of correlation at 0.05 level of significance. The results show that process redesign has positive relationship with employee satisfaction, and work process innovation influences employee retention. The study thus concludes that well-structured work process activities enhance organizational performance.

Carried out a study to identify the critical success factors of BPR implementation in Nigerian oil and gas companies. The data were obtained through 650 self-administered copies of questionnaire to a randomly selected senior and management staff of eight (8) re-engineered Oil and Gas Companies in Nigeria. Using the framework from Khong and Richardson (2003) factors manifesting from operational performance and organizational performance were regressed on the Critical Success Factors (CSFs) manifesting successful BPR. Findings revealed that successful BPR positively affected both performance measures in the Nigerian oil and gas companies.

In Nigeria, Adeyemi and Aremu (2008) examined the impact of reengineering on organizational performance. The study specifically tried to uncover how business process reengineering can help banks to effect innovative and strategic changes in the banking industry in Nigeria. The data for the study were obtained using questionnaire administered on 80 bank staff and analysed through simple percentage analysis and regression analysis. The regression result shows that $\mathrm{BPR}$ can significantly explain about $89 \%$ of the variability in the success of organisational performance. The results further revealed that the business reengineering process, service quality, and innovative and strategic change majorly determine the success of the organisational performance.

Ringim et al. (2012) employed the hierarchical regression analysis to scrutinize the impact of IT capabilities as the moderator on the relationship between BPR factors and organizational performance in Nigerian banks. The stuy found that IT capability moderated the relationship between BPR factors such as change management, customer focus, management commitment and overall organizational performance of bank.

The empirical review so far has shown that studies on BPR resources and firm performance nexus is dearth in both developed and developing economies. The available empirical evidences showed that BPR resources improves firm performance. Specifically, available studies in Nigeria also agreed that BPR and related innovative business improvement brings about enhanced performance (Adeyemi and Aremu, 2008; Ringim et al., 2012; Ogbo et al., 2015; Orogbu et al., 2015). However, no known study in Nigeria identified the possible resources involved in BPR process and their effects on organisational performance. The brewing sector being one of the technologically trending industry will benefit from this study. Validating the empirical and theoretical postulations in Nigerian would provide the policy makers and managers of firms with the management tools to meeting the current competitiveness of the business world. Therefore, the core research gap which the present study wants to fill is to validate the theoretical studies and empirical findings using the Nigerian brewing firms.

\section{Methodology}

\subsection{Research Design}

The descriptive survey design which is a quantitative approach that collects data that describes existing phenomena was adopted. Nworgu (2006) states that descriptive survey design is concerned with collecting data from a sample of a population in order to describe conditions or relationships that exist. The descriptive research design is ideal for this study because the main purpose of the research is essentially theory validation/verification following the hypothetic-deductive approach (Guba and Lincoln, 2005).

\subsection{Population of the Study}

The population of the study consists of the 3500 employees of the brewing firms quoted on the Nigerian Stock Exchange (NSE). There are only five (5) quoted brewing firms in Nigeria as shown on Table 1 below. 
Table-1. List of Quoted Brewing firms in Nigeria.

\begin{tabular}{l|l|l|l}
\hline & Brewing Firms & Acronym & Population \\
\hline 1 & Champion breweries Plc. & CHAMPION & 435 \\
\hline 2 & Guinness Nig. Plc. & GUINNESS & 654 \\
\hline 3 & International Breweries Plc. & INTBREW & 499 \\
\hline 4 & Jos International Breweries Plc. & JOSBREW & 629 \\
\hline 5 & Nigerian breweries Plc. & NB & 1283 \\
\hline & Total & & $\mathbf{3 , 5 0 0}$ \\
\hline
\end{tabular}

The population of the study comprised all the top and middle management of the brewing firms. These include the General Manager/CEO, Production manager, Finance manager/head of accounts department, Marketing manager, Procurement manager/head of purchase department, Human resource manager/head of personnel department, Sales representatives. In a nutshell, all General Managers of the firms, managers and assistant managers in the various departments were used for the study.

\subsection{Sample and Sampling Technique}

The study adopted a random sampling technique to select 746 management staff of the brewing firms in Nigeria. A mathematical model developed by was used to determine the sample size: $\mathrm{n}=(\mathrm{Za})^{2}(\mathrm{e})(\mathrm{N})$, where $\mathrm{n}=$ Sample size, $\mathrm{Z}=$ confidence level, usually 1.961 , e = error factor $(0.05)$ and $\mathrm{N}=$ population of the selected brewing firms (3500). In this study the researcher will work on 95\% confidence level. Applying the above model, we have: $(1.961)^{2} \times 0.05 \times 3500=672$.Anticipating a response rate of $90 \%$, an adjustment of the sample size estimate to cover for non-response rate was made by dividing the sample size calculated with a factor, $\mathrm{f}$ i.e. $\mathrm{n} / \mathrm{f}$, where $\mathrm{f}$ is the estimated response rate. The calculated sample size $=672 / 0.90=746$. Therefore, the sample size for the study is 746 respondents.

Thus the researcher used 746 persons as sample size for the study. Thus, simple proportion method was used to allocate the sample size allocated as follows:
i. CHAMPION
$=\frac{435}{3,500} \times \frac{746}{1}=93$
ii. GUINNESS
$=\frac{654}{3,500} \times \frac{746}{1}=139$
iii. INTBREW
$=\frac{499}{3,500} \times \frac{746}{1}=106$
iv. JOSBREW
$=\frac{629}{3,500} \times \frac{746}{1}=134$
v. NB
$=\frac{1283}{3,500} \times \frac{746}{1}=274$
Grand Total

$=746$ respondents

\subsection{Instrument of the Study}

The instrument for data collection was structured in a Likert-scale format. The choice of the Likert scale was informed by the fact that it presents the respondents with the opportunity of indicating the extent to which they agree or disagree with the statements of the item. The questionnaire used a 6-point scale to capture the items in resources. It divided BPR resources into financial, human and technological. However, organisation performance construct was operationalized with 4 items to measure attainment of strategic goals and objectives, employee satisfaction, teamwork and cooperative/collaborative working culture and service delivery and/or operation capacity with a 5-point Likert type of Very Low (VL), Low (L), Moderate (M), High (H) and Very High (VH).

\subsection{Reliability of the Instrument}

Reliability of the instrument was determined through a test of internal consistency of the question items in each of the constructs. The internal consistency is usually calculated using an alpha coefficient, which measures the interrelationship between items in the questionnaire (Cortina, 1993). Nunally (1978) argues that a reliability of 0.70 or higher is acceptable. The Cronbach alphas all ranked higher than 0.70 (actual scores were 0.79). This analysis showed an alpha of 0.85 , indicating that the scales used in the study are reliable.

\subsection{Model Specification}

The constructs as adapted from Kassahun (2012) was based on the postulation that BPR resource has positive effect on organisational performance. Thus, the models are developed as follows:

$$
\mathrm{OP}=f(\mathrm{FR}, \mathrm{HR}, \mathrm{TR})
$$

In this model, Organisational performance $(\mathrm{OP})$ is the dependent, while the variables of BPR resource are the independent variables: Financial resources (FR), Human resources (HR) and Technological resources (TR). The equation is rewritten in a model as follows:

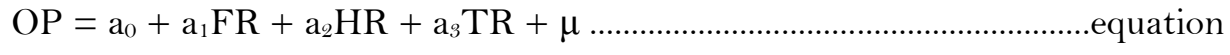

Where:

$\mathrm{OP}=$ Organisational performance and the dependent variables.

$\mathrm{FR}=$ Financial resources

$\mathrm{HR}=$ Human resources.

$\mathrm{TR}=$ Technological resources.

Where $\mathrm{a}_{0}$ is a constant or intercept. $\mathrm{a}_{1}, \mathrm{a}_{2}$, and $\mathrm{a}_{3}$, are the coefficients of the explanatory variables. $\mu$ is the stochastic error term. 


\subsection{Method of Analyses}

The Ordinary Least Square regression technique was adopted in the analysis of the relationship between dependent variables and the independent variables in each of the models. Data from Likert scale responses are ordinal scale which tend not to have normal distribution, however, Norman (2010) cited in Gail and Artino (2013) has proved that parametric tests not only can be used with ordinal data such as Likert scale but also that parametric tests are more robust than non-parametric tests. "This means that parametric tests tend to give the right answer" even when statistical assumptions such as normal distribution of data are violated to an extreme degree: Thus "parametric tests are sufficiently robust to yield largely unbiased answers that are acceptably close to "the truth" when analysing Likert scale responses".

\section{Results and Interpretation}

746 copies of the questionnaires were distributed and 684 were duly completed and returned. The response rate of the questionnaire was $91.69 \%$.

\subsection{Descriptive Analyses of the Nature of BPR Resources and Performance of Brewing Firms in Nigeria}

The BPR resources are grouped into financial, human and technological resources. The analysis aims to find out the level of use of each of these resources. The results from Tables 2, 3 and 5 showed the level of usage of BPR resources in the firms, while Table 5 is the analysis of level of organisational performance among brewing firms in Nigeria.

Table-2. Financial (budgetary) resources deployed during the implementation of BPR project in Brewing firms

\begin{tabular}{|c|c|c|c|c|c|c|c|c|}
\hline $\mathbf{S N}$ & Financial Resource variables & NU & VLU & LU & MU & $\mathbf{A U}$ & VAU & Remark \\
\hline 1 & BPR training & $\begin{array}{l}0 \\
(0 \%)\end{array}$ & $\begin{array}{l}86 \\
(12.6 \%)\end{array}$ & $\begin{array}{l}132 \\
(19.3 \%)\end{array}$ & $\begin{array}{l}64 \\
(9.4 \%)\end{array}$ & $\begin{array}{l}334 \\
(48.8 \%)\end{array}$ & $\begin{array}{l}68 \\
(9.9 \%)\end{array}$ & Adequate usage \\
\hline 2 & $\begin{array}{ll}\text { BPR associated } & \text { IT } \\
\text { investments } & \\
\end{array}$ & $\begin{array}{l}6 \\
(0.9 \%) \\
\end{array}$ & $\begin{array}{l}92 \\
(13.5 \%)\end{array}$ & $\begin{array}{l}124 \\
(18.1 \%) \\
\end{array}$ & $\begin{array}{l}82 \\
(11.9 \%)\end{array}$ & $\begin{array}{l}290 \\
(42.4 \%)\end{array}$ & $\begin{array}{l}90 \\
(13.2 \%)\end{array}$ & Adequate usage \\
\hline 3 & BPR benchmarking tours & $\begin{array}{l}8 \\
(1.2 \%) \\
\end{array}$ & $\begin{array}{l}48 \\
(7.0 \%)\end{array}$ & $\begin{array}{l}120 \\
(17.5 \%)\end{array}$ & $\begin{array}{l}152 \\
(22.2 \%)\end{array}$ & $\begin{array}{l}198 \\
(28.9 \%)\end{array}$ & $\begin{array}{l}158 \\
(23.1 \%)\end{array}$ & Adequate usage \\
\hline 4 & $\begin{array}{l}\text { BPR associated office layout } \\
\text { reorganisation }\end{array}$ & $\begin{array}{l}0 \\
(0 \%)\end{array}$ & $\begin{array}{l}24 \\
(3.5 \%)\end{array}$ & $\begin{array}{l}86 \\
(12.6 \%)\end{array}$ & $\begin{array}{l}112 \\
(16.4 \%)\end{array}$ & $\begin{array}{l}120 \\
(17.5 \%)\end{array}$ & $\begin{array}{l}342 \\
(50.0 \%)\end{array}$ & $\begin{array}{ll}\text { Very } & \text { adequate } \\
\text { usage } & \\
\end{array}$ \\
\hline \multirow[t]{2}{*}{5} & BPR consultants & $\begin{array}{l}34 \\
(5.0 \%)\end{array}$ & $\begin{array}{l}68 \\
(9.9 \%)\end{array}$ & $\begin{array}{l}134 \\
(19.6 \%)\end{array}$ & $\begin{array}{l}228 \\
(33.3 \%)\end{array}$ & $\begin{array}{l}130 \\
(19.0 \%)\end{array}$ & $\begin{array}{l}90 \\
(13.2 \%)\end{array}$ & Moderate usage \\
\hline & $\begin{array}{l}\text { Cumulative } \\
\text { Response }\end{array}$ & $1 \%$ & $9 \%$ & $17 \%$ & $19 \%$ & $31 \%$ & $22 \%$ & Adequate usage \\
\hline
\end{tabular}

Key: No use (NU), Very Low Usage (VLU), Low Usage (LU), Moderate Usage (MU), Adequate Usage (AU), Very Adequate Usage (VAU)

The results shown in Table 2 describe the level of financial resource usage in the BPR implementation process. The results from frequency counts showed that training, IT investment, and benchmarking tours received "adequate usage" while the usage of office layout reorganisation, and consultants were "very adequate" and "moderate" respectively.

The summary of the results were shown as cumulative average response. It showed that $1 \%$ of the respondents indicated that financial resources were not used, $9 \%$ said it had very low usage, and $17 \%$ recorded low usage. More so, 19\%, 31\% and 22\% showed moderate, adequate and very adequate usages respectively. The overall response indicated that there is an "adequate usage" of financial resources in the BPR implementation in the brewing firms under study. The graphic presentation of the result is shown on Figure 1.

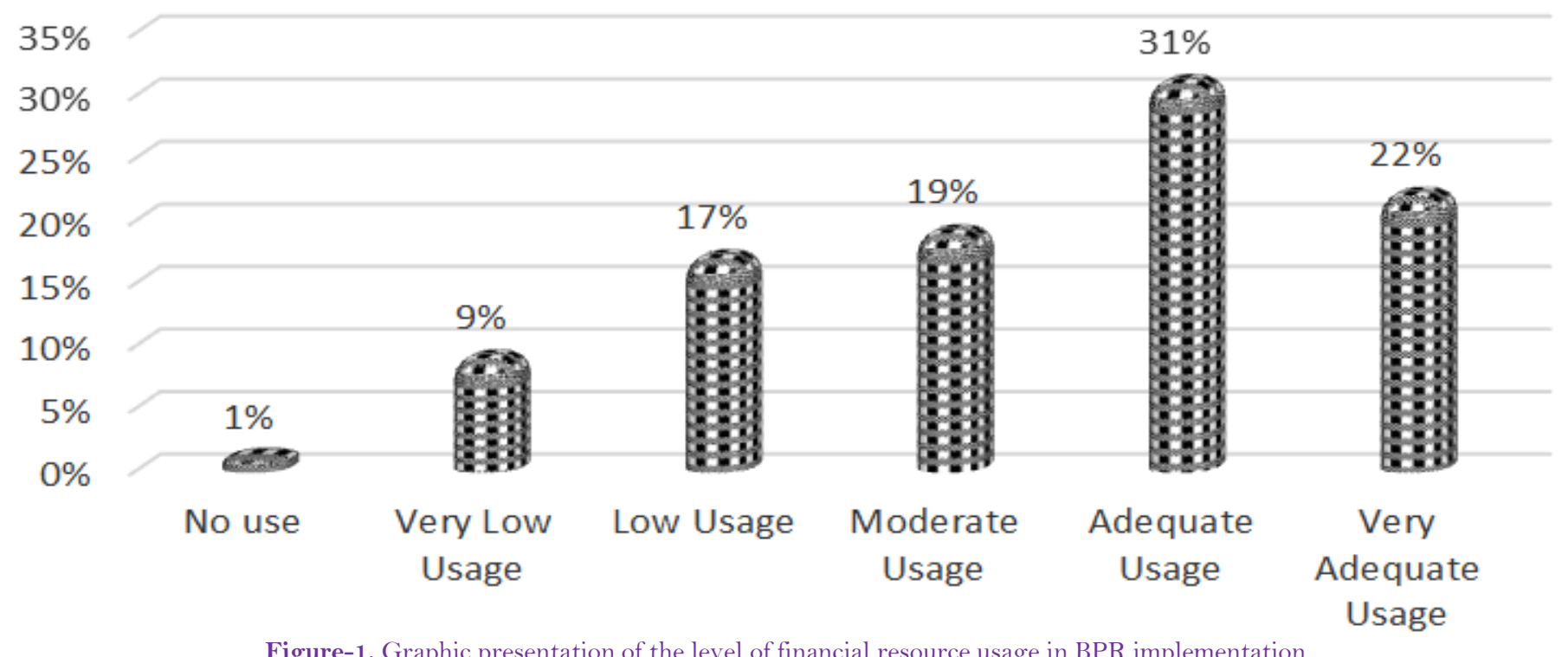

Source: Field survey 2018 
Table-3. Knowledge and skill of the human resources deployed during the implementation of BPR

\begin{tabular}{|c|c|c|c|c|c|c|c|c|}
\hline $\mathbf{S N}$ & $\begin{array}{ll}\text { Human } & \text { Resource } \\
\text { Variables } & \\
\end{array}$ & NU & VLU & LU & MU & $\overline{\mathrm{AU}}$ & VAU & Remark \\
\hline 6 & Role of IT in BPR & $\begin{array}{l}\mathrm{O} \\
(\mathrm{O} \%)\end{array}$ & $\begin{array}{l}8 \\
(1.2 \%) \\
\end{array}$ & $\begin{array}{l}24 \\
(3.5 \%)\end{array}$ & $\begin{array}{l}130 \\
(19.0 \%)\end{array}$ & $\begin{array}{l}214 \\
(31.2 \%)\end{array}$ & $\begin{array}{l}308 \\
(45.0 \%)\end{array}$ & Adequate usage \\
\hline 7 & Change management & $\begin{array}{l}0 \\
(0 \%)\end{array}$ & $\begin{array}{l}10 \\
(1.3 \%) \\
\end{array}$ & $\begin{array}{l}242 \\
(35.4 \%)\end{array}$ & $\begin{array}{l}174 \\
(25.4 \%)\end{array}$ & $\begin{array}{l}126 \\
(18.4 \%)\end{array}$ & $\begin{array}{l}132 \\
(19.3 \%)\end{array}$ & Low Usage \\
\hline 8 & $\begin{array}{l}\text { Core } \\
\text { functions/activities }\end{array}$ & $\begin{array}{l}\mathrm{O} \\
(\mathrm{O} \%)\end{array}$ & $\begin{array}{l}\mathrm{O} \\
(\mathrm{O} \%)\end{array}$ & $\begin{array}{l}64 \\
(9.4 \%)\end{array}$ & $\begin{array}{l}84 \\
(12.3 \%)\end{array}$ & $\begin{array}{l}96 \\
(14.0 \%)\end{array}$ & $\begin{array}{l}440 \\
(64.3 \%)\end{array}$ & $\begin{array}{ll}\text { Very } & \text { adequate } \\
\text { usage } & \end{array}$ \\
\hline 9 & $\begin{array}{l}\text { Performance } \\
\text { measurement }\end{array}$ & $\begin{array}{l}4 \\
(0.6 \%) \\
\end{array}$ & $\begin{array}{l}10 \\
(1.3 \%) \\
\end{array}$ & $\begin{array}{l}90 \\
(13.2 \%) \\
\end{array}$ & $\begin{array}{l}290 \\
(42.4 \%) \\
\end{array}$ & $\begin{array}{l}160 \\
(23.4 \%) \\
\end{array}$ & $\begin{array}{l}130 \\
(19.0 \%)\end{array}$ & Moderate usage \\
\hline 10 & Communication & $\begin{array}{l}\mathrm{O} \\
(\mathrm{O} \%)\end{array}$ & $\begin{array}{l}\mathrm{O} \\
(\mathrm{O} \%)\end{array}$ & $\begin{array}{l}60 \\
(8.8 \%)\end{array}$ & $\begin{array}{l}88 \\
(12.9 \%)\end{array}$ & $\begin{array}{l}116 \\
(17.0 \%)\end{array}$ & $\begin{array}{l}420 \\
(61.4 \%)\end{array}$ & $\begin{array}{ll}\text { Very } & \text { adequate } \\
\text { usage } & \end{array}$ \\
\hline 11 & $\begin{array}{l}\text { Stakeholder } \\
\text { engagement }\end{array}$ & $\begin{array}{l}\mathrm{O} \\
(\mathrm{O} \%)\end{array}$ & $\begin{array}{l}\mathrm{O} \\
(\mathrm{O} \%)\end{array}$ & $\begin{array}{l}2 \\
(0.3)\end{array}$ & $\begin{array}{l}2 \\
(0.3 \%)\end{array}$ & $\begin{array}{l}114 \\
(16.7 \%)\end{array}$ & $\begin{array}{l}566 \\
(82.7 \%)\end{array}$ & $\begin{array}{lr}\text { Very } & \text { adequate } \\
\text { usage } & \end{array}$ \\
\hline 12 & $\begin{array}{l}\text { design and } \\
\text { implementation project }\end{array}$ & $\begin{array}{l}28 \\
(4.1 \%) \\
\end{array}$ & $\begin{array}{l}80 \\
(11.7 \%)\end{array}$ & $\begin{array}{l}108 \\
(15.8 \%)\end{array}$ & $\begin{array}{l}230 \\
(33.6 \%)\end{array}$ & $\begin{array}{l}152 \\
(22.3 \%)\end{array}$ & $\begin{array}{l}86 \\
(12.6 \%)\end{array}$ & Moderate usage \\
\hline & $\begin{array}{l}\text { Cumulative Average } \\
\text { Response }\end{array}$ & $4.1 \%$ & $11.7 \%$ & $15.8 \%$ & $33.6 \%$ & $22.2 \%$ & $12.6 \%$ & Moderate usage \\
\hline
\end{tabular}

From the result on Table 3, it can be seen that most of the human resources - role of IT (45\%), core functions/ activities (64.3\%), communication (61.4\%), and stakeholder engagement (82.7\%) are rated as very adequate in use by the respondents. However, Performance measurement (42.4\%), design and implementation project (33.6\%) are indicated as moderate usage while Change management (35.4\%) was in low usage.

The overall result indicate that there is a "moderate" deployment of human resources during the implementation of BPR in brewing firms in Nigeria. As depicted in Figure 6, "moderate" has the highest bar with 33.6 percent, followed by "Adequate Usage" with 22.2\%. However, "No Use", "very Low usage", Low Usage" and Very Adequate Usage" were $4.1 \%, 11.7 \%, 15.8 \%$ and $12.6 \%$ respectively. These results indicate that there is an overall moderate usage of human resources in Nigerian brewing firms.

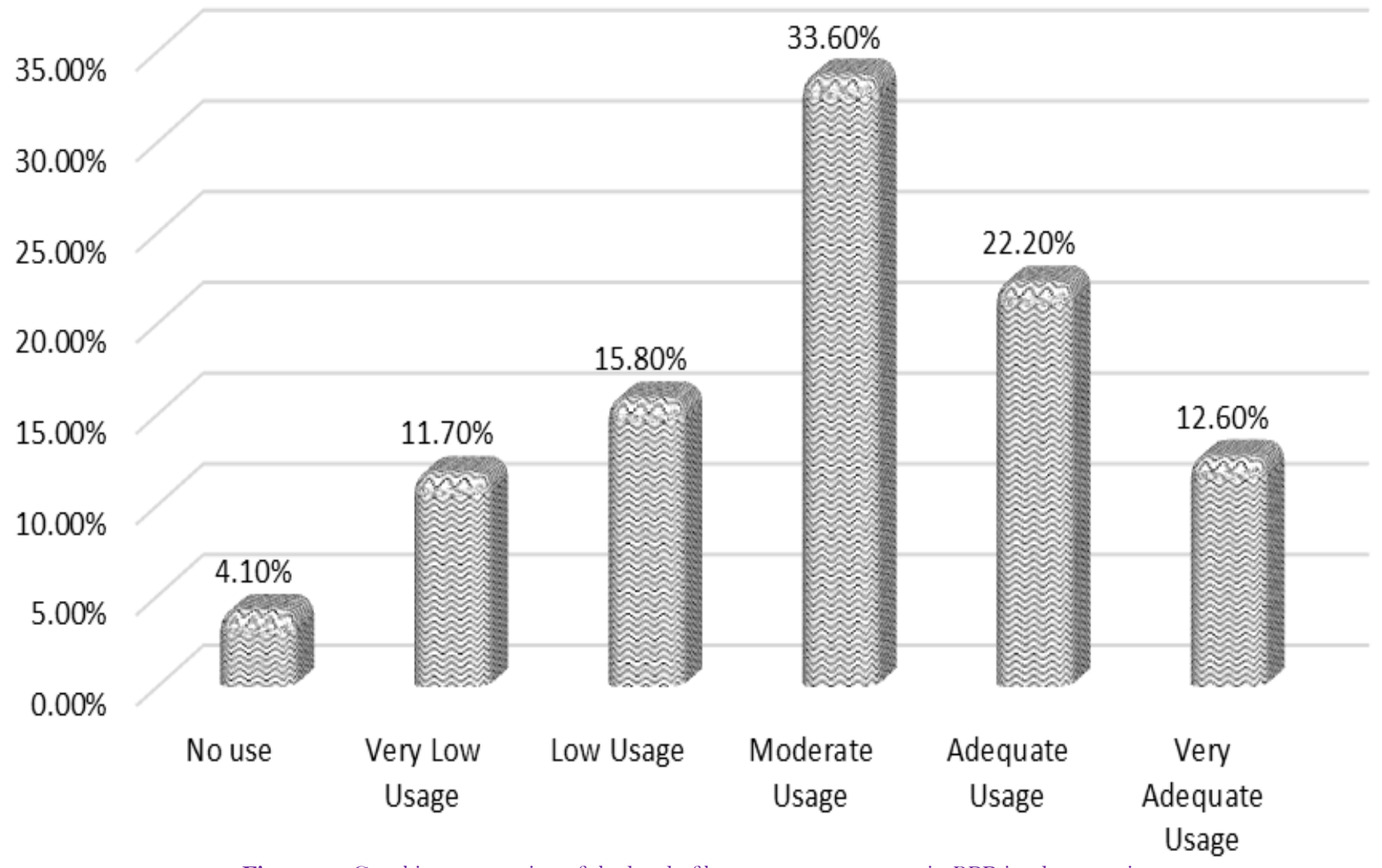

Source: field survey 2017

Figure-2. Graphic presentation of the level of human resource usage in BPR implementation

The result in Table 4 shows the level of technological resources deployed in brewing firms in Nigeria. The technological resource variables are represented by items 13 to 27 in the Table. The results show that most of the items questions received "adequate usage" as indicated by the respondents. According to the result, the items of technological resource that were in "adequate usage" included "Automated workflow \& document flow system" (54.7\%), "Website for publishing basic organizational information" (34.2\%), "Shared IT infrastructure" (51.2\%), "Computerized budget and expenditure system" (36.3\%), "Computerized human resource management (personnel) system” (45.6\%), and "Computerized process management, monitoring, and reporting system” (51.2\%). 
Table-4.Technological resources deployed for the BPR implementation

\begin{tabular}{|c|c|c|c|c|c|c|c|c|}
\hline & Technological Resource Variables & NU & VLU & $\mathbf{L U}$ & MU & $\mathbf{A U}$ & VAU & Remark \\
\hline 13 & $\begin{array}{l}\text { Automated workflow } \quad \& \\
\text { document flow system }\end{array}$ & $\begin{array}{l}0 \\
(0 \%)\end{array}$ & $\begin{array}{l}0 \\
(0 \%)\end{array}$ & $\begin{array}{l}40 \\
(5.8 \%)\end{array}$ & $\begin{array}{l}90 \\
(13.2 \%)\end{array}$ & $\begin{array}{l}174 \\
(54.7 \%)\end{array}$ & $\begin{array}{l}180 \\
(26.3 \%)\end{array}$ & $\begin{array}{l}\text { Adequate } \\
\text { Usage }\end{array}$ \\
\hline 14 & $\begin{array}{l}\text { Website for publishing } \\
\text { information about services of the } \\
\text { organization }\end{array}$ & $(\mathrm{O} \%)$ & $\begin{array}{l}52 \\
(7.6 \%)\end{array}$ & $\begin{array}{l}156 \\
(22.8 \%)\end{array}$ & $\begin{array}{l}242 \\
(35.4 \%)\end{array}$ & $\begin{array}{l}152 \\
(22.2 \%)\end{array}$ & $\begin{array}{l}82 \\
(12.0 \%)\end{array}$ & $\begin{array}{l}\text { Moderate } \\
\text { Usage }\end{array}$ \\
\hline 15 & $\begin{array}{l}\text { Website for publishing basic } \\
\text { organizational information }\end{array}$ & $\begin{array}{l}\mathrm{O} \\
(\mathrm{O} \%) \\
\end{array}$ & $\begin{array}{l}42 \\
(6.1 \%) \\
\end{array}$ & $\begin{array}{l}134 \\
(19.6 \%)\end{array}$ & $\begin{array}{l}164 \\
(24.0 \%)\end{array}$ & $\begin{array}{l}234 \\
(34.2 \%)\end{array}$ & $\begin{array}{l}110 \\
(16.1 \%)\end{array}$ & $\begin{array}{l}\text { Adequate } \\
\text { Usage }\end{array}$ \\
\hline 16 & Teleconferencing technologies & $\begin{array}{l}0 \\
(0 \%)\end{array}$ & $\begin{array}{l}52 \\
(7.6 \%)\end{array}$ & $\begin{array}{l}334 \\
(48.8 \%)\end{array}$ & $\begin{array}{l}146 \\
(21.3 \%)\end{array}$ & $\begin{array}{l}88 \\
(12.9 \%)\end{array}$ & $\begin{array}{l}64 \\
(9.4 \%)\end{array}$ & Low Usage \\
\hline 17 & $\begin{array}{l}\text { Electronic communication media } \\
\text { for formal external } \\
\text { communication }\end{array}$ & $\begin{array}{l}\mathrm{O} \\
(\mathrm{O} \%)\end{array}$ & $\begin{array}{l}70 \\
(10.2 \%)\end{array}$ & $\begin{array}{l}112 \\
(16.4 \%)\end{array}$ & $\begin{array}{l}244 \\
(35.7 \%)\end{array}$ & $\begin{array}{l}156 \\
(22.8 \%)\end{array}$ & $\begin{array}{l}102 \\
(14.9 \%)\end{array}$ & $\begin{array}{l}\text { Moderate } \\
\text { Usage }\end{array}$ \\
\hline 18 & $\begin{array}{l}\text { Electronic communication media } \\
\text { for internal communications }\end{array}$ & $\begin{array}{l}\mathrm{O} \\
(\mathrm{O} \%)\end{array}$ & $\begin{array}{l}64 \\
(9.4 \%)\end{array}$ & $\begin{array}{l}102 \\
(14.9 \%)\end{array}$ & $\begin{array}{l}116 \\
(17.0 \%)\end{array}$ & $\begin{array}{l}180 \\
(26.3 \%)\end{array}$ & $\begin{array}{l}222 \\
(32.55)\end{array}$ & $\begin{array}{l}\text { Very } \\
\text { Adequate } \\
\text { Usage }\end{array}$ \\
\hline 19 & Shared IT infrastructure & $\begin{array}{l}\mathrm{O} \\
(\mathrm{O} \%)\end{array}$ & $\begin{array}{l}2 \\
(0.3 \%) \\
\end{array}$ & $\begin{array}{l}34 \\
(5.0 \%) \\
\end{array}$ & $\begin{array}{l}112 \\
(16.4 \%)\end{array}$ & $\begin{array}{l}350 \\
(51.2 \%)\end{array}$ & $\begin{array}{l}186 \\
(27.2 \%)\end{array}$ & $\begin{array}{l}\text { Adequate } \\
\text { Usage }\end{array}$ \\
\hline 20 & $\begin{array}{l}\text { Computerized procurement } \\
\text { system }\end{array}$ & $\begin{array}{l}0 \\
(0 \%) \\
\end{array}$ & $\begin{array}{l}64 \\
(9.4 \%)\end{array}$ & $\begin{array}{l}154 \\
(22.5 \%)\end{array}$ & $\begin{array}{l}240 \\
(35.1 \%) \\
\end{array}$ & $\begin{array}{l}148 \\
(21.6 \%) \\
\end{array}$ & $\begin{array}{l}78 \\
(11.4 \%) \\
\end{array}$ & $\begin{array}{l}\text { Moderate } \\
\text { Usage }\end{array}$ \\
\hline 21 & $\begin{array}{l}\text { Computerized budget and } \\
\text { expenditure system }\end{array}$ & $\begin{array}{l}0 \\
(0 \%)\end{array}$ & $\begin{array}{l}30 \\
(4.4 \%)\end{array}$ & $\begin{array}{l}128 \\
(18.7 \%)\end{array}$ & $\begin{array}{l}162 \\
(23.7 \%)\end{array}$ & $\begin{array}{l}248 \\
(36.3 \%)\end{array}$ & $\begin{array}{l}116 \\
(17.0 \%)\end{array}$ & $\begin{array}{l}\text { Adequate } \\
\text { Usage }\end{array}$ \\
\hline 22 & $\begin{array}{l}\text { Computerized human resource } \\
\text { management (personnel) system }\end{array}$ & $\begin{array}{l}0 \\
(0 \%)\end{array}$ & $\begin{array}{l}46 \\
(6.7 \%)\end{array}$ & $\begin{array}{l}90 \\
(13.2 \%)\end{array}$ & $\begin{array}{l}134 \\
(20.0 \%)\end{array}$ & $\begin{array}{l}312 \\
(45.6 \%)\end{array}$ & $\begin{array}{l}102 \\
(14.9 \%)\end{array}$ & $\begin{array}{l}\text { Adequate } \\
\text { Usage }\end{array}$ \\
\hline 23 & $\begin{array}{l}\text { Document management / } \\
\text { archival system }\end{array}$ & $(0 \%)$ & $\begin{array}{l}68 \\
(9.9 \%)\end{array}$ & $\begin{array}{l}114 \\
(16.7 \%)\end{array}$ & $\begin{array}{l}248 \\
(36.0 \%)\end{array}$ & $\begin{array}{l}152 \\
(22.2 \%)\end{array}$ & $\begin{array}{l}104 \\
(15.2 \%)\end{array}$ & $\begin{array}{l}\text { Moderate } \\
\text { Usage }\end{array}$ \\
\hline 24 & $\begin{array}{l}\text { Computerized } \begin{array}{l}\text { performance } \\
\text { measurement and reporting } \\
\text { system }\end{array} \\
\end{array}$ & $\begin{array}{l}\mathrm{O} \\
(\mathrm{O} \%)\end{array}$ & $\begin{array}{l}64 \\
(9.4 \%)\end{array}$ & $\begin{array}{l}104 \\
(15.2 \%)\end{array}$ & $\begin{array}{l}118 \\
(17.3 \%)\end{array}$ & $\begin{array}{l}184 \\
(26.9 \%)\end{array}$ & $\begin{array}{l}214 \\
(31.3 \%)\end{array}$ & $\begin{array}{l}\text { Very } \\
\text { Adequate } \\
\text { Usage }\end{array}$ \\
\hline 25 & $\begin{array}{l}\text { Computerized process } \\
\text { management, monitoring, and } \\
\text { reporting system }\end{array}$ & $\begin{array}{l}\mathrm{O} \\
(\mathrm{O} \%)\end{array}$ & $\begin{array}{l}2 \\
(0.3 \%)\end{array}$ & $\begin{array}{l}34 \\
(5.0 \%)\end{array}$ & $\begin{array}{l}112 \\
(16.4 \%)\end{array}$ & $\begin{array}{l}350 \\
(51.2 \%)\end{array}$ & $\begin{array}{l}186 \\
(27.2 \%)\end{array}$ & $\begin{array}{l}\text { Adequate } \\
\text { Usage }\end{array}$ \\
\hline 26 & Online delivery of services & $\begin{array}{l}10 \\
(1.5 \%) \\
\end{array}$ & $\begin{array}{l}46 \\
(6.7 \%) \\
\end{array}$ & $\begin{array}{l}330 \\
(48.2 \%)\end{array}$ & $\begin{array}{l}132 \\
(19.3 \%)\end{array}$ & $\begin{array}{l}90 \\
(13.2 \%)\end{array}$ & $\begin{array}{l}76 \\
(11.1 \%)\end{array}$ & Low Usage \\
\hline \multirow[t]{2}{*}{27} & Queue management system & $\begin{array}{l}4 \\
(0.6 \%)\end{array}$ & $\begin{array}{l}70 \\
(10.2 \%)\end{array}$ & $\begin{array}{l}136 \\
(19.9 \%)\end{array}$ & $\begin{array}{l}236 \\
(34.5 \%)\end{array}$ & $\begin{array}{l}158 \\
(23.1 \%)\end{array}$ & $\begin{array}{l}80 \\
(11.7 \%)\end{array}$ & $\begin{array}{l}\text { Moderate } \\
\text { Usage }\end{array}$ \\
\hline & Cumulative Average Response & $0.1 \%$ & $6.5 \%$ & $19.5 \%$ & $24.4 \%$ & $31.0 \%$ & $23.3 \%$ & $\begin{array}{l}\text { Adequate } \\
\text { Usage }\end{array}$ \\
\hline
\end{tabular}

Key: No use (NU), Very Low Usage (VLU), Low Usage (LU), Moderate Usage (MU), Adequate Usage (AU), Very Adequate Usage (VAU)

Closely following the items that received adequate usage (six items) is the ones with "moderate usage" (five items). These include "Website for publishing information about services of the organization" (35.4\%), "Electronic communication media for formal external communication" (35.7\%), "Computerized procurement system" (35.2\%), "Document management / archival system" (36.0\%), and "Queue management system” (34.5\%). However, few of the items that received Low Usage included "Teleconferencing technologies" (48.8\%) and "Online delivery of services" (48.2\%) while "Electronic communication media for internal communications" (32.55\%) and "Computerized performance measurement and reporting system" $31.3 \%)$ were in very adequate usage respectively.

The overall result showed that technological resources received "adequate usage" in brewing firms. This is affirmed from result on Figure 7 showing overall responses with adequate usage as $31 \%$, very adequate usage with $23.3 \%$, moderate usage with $24.4 \%$, low usage with $19.5 \%$, very low usage with $6.5 \%$ and no use as $0.1 \%$. Thus the overall result is that technological resources were in adequate usage in brewing firms in Nigeria.

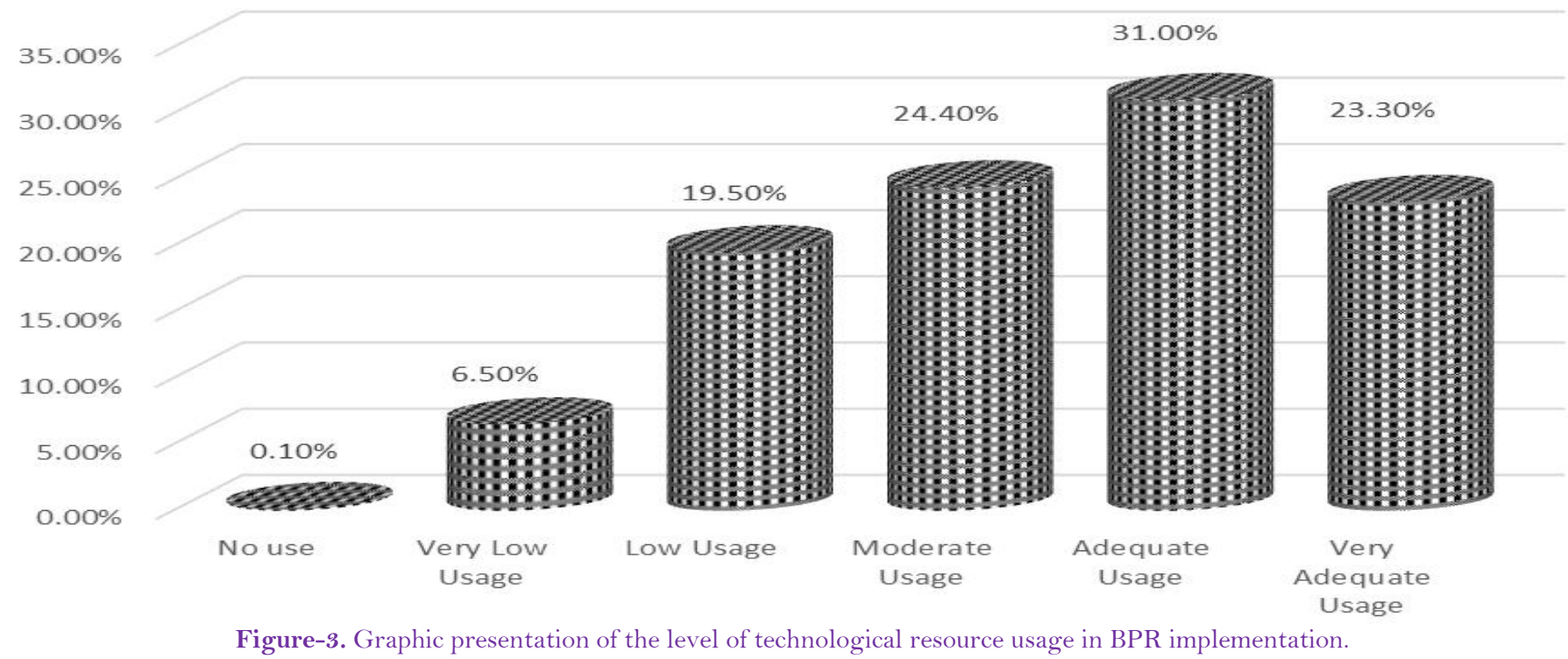

Source: field survey 2017

Figure-3. Graphic presentation of the level of technological resource usage in BPR implementation.

In summary, the results from Tables 1, 2 and 3, as well as Figures 1, 2, and 3 showed that financial, human and technological resources were variously used in brewing firms in Nigeria. Financial and technological resources 
were in adequate usage while human resources was moderate. This suggests that operations in brewing firms are more capital (financial) and technological based than human. Generally, the results indicate that resource use in brewing firms is needful.

Table-5. Analyses of improvement in Organisational Performance

\begin{tabular}{|c|c|c|c|c|c|c|c|}
\hline $\mathbf{S N}$ & Indicators & Very low & Low & Moderate & High & Very high & Remark \\
\hline 1 & $\begin{array}{l}\text { Attainment of organizational strategic } \\
\text { goals and objectives }\end{array}$ & $\begin{array}{l}4 \\
(0.6 \%) \\
\end{array}$ & $\begin{array}{l}44 \\
(6.4 \%)\end{array}$ & $\begin{array}{l}112 \\
(16.4 \%)\end{array}$ & $\begin{array}{l}352 \\
(51.5 \%)\end{array}$ & $\begin{array}{l}172 \\
(25.1 \%)\end{array}$ & High \\
\hline 2 & Employee satisfaction & $\begin{array}{l}38 \\
(5.6 \%) \\
\end{array}$ & $\begin{array}{l}108 \\
(15.8 \%)\end{array}$ & $\begin{array}{l}320 \\
(46.8 \%)\end{array}$ & $\begin{array}{l}128 \\
(18.7 \%)\end{array}$ & $\begin{array}{l}90 \\
(13.2 \%)\end{array}$ & Moderate \\
\hline 3 & $\begin{array}{l}\text { Teamwork and cooperative/ } \\
\text { collaborative working culture }\end{array}$ & $\begin{array}{ll}0 \\
(0 \%)\end{array}$ & $\begin{array}{l}42 \\
(6.1 \%)\end{array}$ & $\begin{array}{l}94 \\
(13.7 \%)\end{array}$ & $\begin{array}{l}374 \\
(54.7 \%)\end{array}$ & $\begin{array}{l}174 \\
(25.4 \%)\end{array}$ & High \\
\hline 4 & Cumulative Average Response & $2.20 \%$ & $10.65 \%$ & $24.35 \%$ & $37.23 \%$ & $25.58 \%$ & High \\
\hline
\end{tabular}

Source: field survey 2017

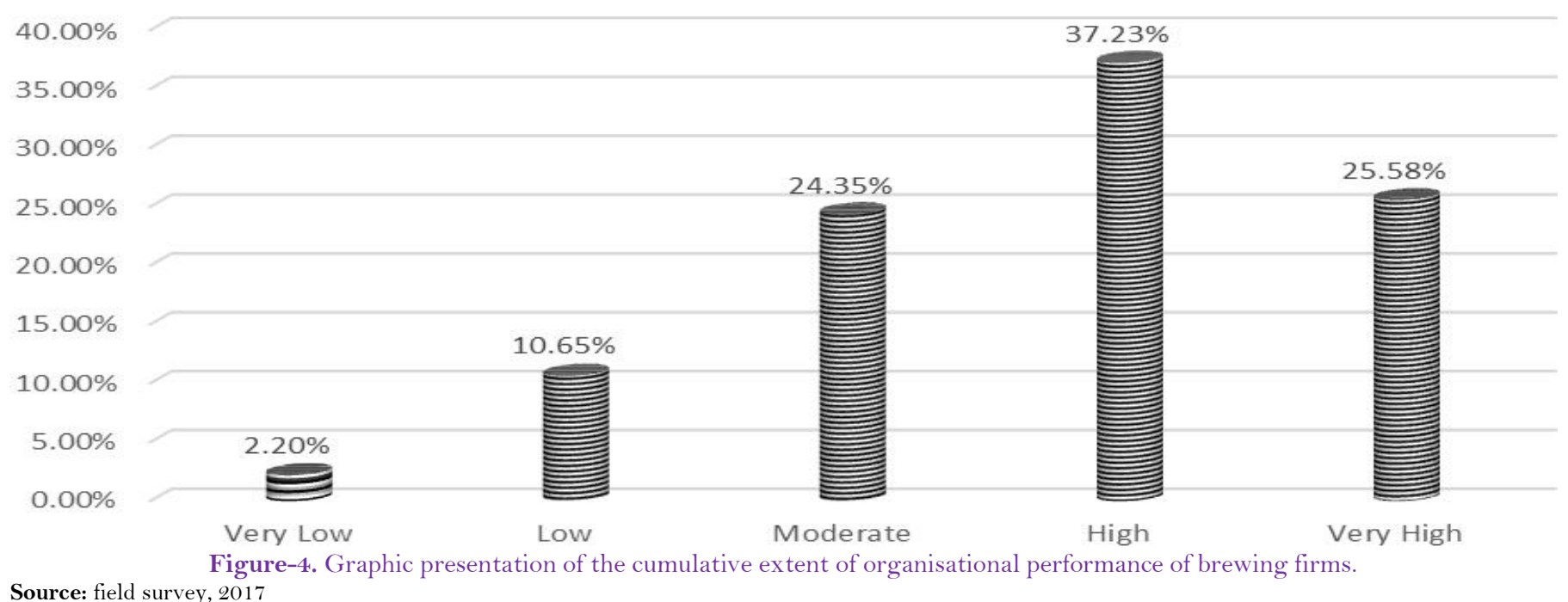

Source: field survey, 2017

The level of organisational performance is measured using four variables covering (1) attainment of organizational strategic goals and objectives, (2) employee satisfaction such as more empowerment in skill \& knowledge, decision making power, better/quality working condition/environment, (3) teamwork and cooperative/collaborative working culture in the areas of better employee cooperation, information sharing, and overall organizational collaboration, and (4) service delivery and/or operation capacity such as efficiency, productivity, service type variety, service provision quality and service expansion.

Among these measures of performance, Attainment of organizational strategic goals and objectives (51.5\%) and Teamwork and cooperative/ collaborative working culture $(54.7 \%)$ scored "high" in performance rating while "Employee satisfaction" (46.7\%) and "service delivery and/or operation capacity" (38.6\%) scores "moderate" and "very high" respectively.

From the cumulative average response shown on Figure 4, very low received 2.2\% score, low received $10.65 \%$, moderate got $24.23 \%$, while high and very high scored $37.23 \%$ and $25.58 \%$ respectively. The results suggest that the performance of brewing firms in Nigeria at present is scored high in the five-point rating.

\subsection{Test of Reliability of Models}

There is every tendency that the independent variables employed in each model may have high correlation among one another, and this is capable of affecting the reliability of the results from such models. Thus the test of multicolinearity is done to determine the reliability of each model. The Variance Inflation Factor (VIF) has been adopted to test for the presence of multicolinearity in the models.

Decision Rule: "When the value of VIF is 10 and above, then the multicolinearity is problematic (Ranjit, 2006).

\begin{tabular}{|c|c|c|c|}
\hline \multirow[t]{2}{*}{ Model } & & \multicolumn{2}{|c|}{ Collinearity Statistics } \\
\hline & & Tolerance & VIF \\
\hline & (Constant) & & \\
\hline & FR & .196 & 5.094 \\
\hline & HR & .286 & 3.499 \\
\hline & TR & .311 & 3.220 \\
\hline
\end{tabular}

Table 6 shows the VIF for the independent variables of BPR Resource model. The result indicates that Financial Resources (FR), Human Resources (HR), and Technological Resources had VIF values of 5.094, 3.499 and 3.220, respectively. Since the values are not more than 10 , we conclude that there is no multicolinearity in the model. Thus the model for BPR Resources is adjudged reliable for OLS regression analyses. 


\subsection{Model Estimation}

Having analysed the status of the variables employed in the study, the study then performed the regression analyses to show the effect of the independent variables (BPR perspectives /activities) on organisational performance of brewing firms in Nigeria. From the analyses, the research questions were answered using the standardised coefficient of regression (beta) while the hypotheses were tested with F-Statistics and t-statistics.

Table-7. Regression of the effect of BPR resources on firm performance

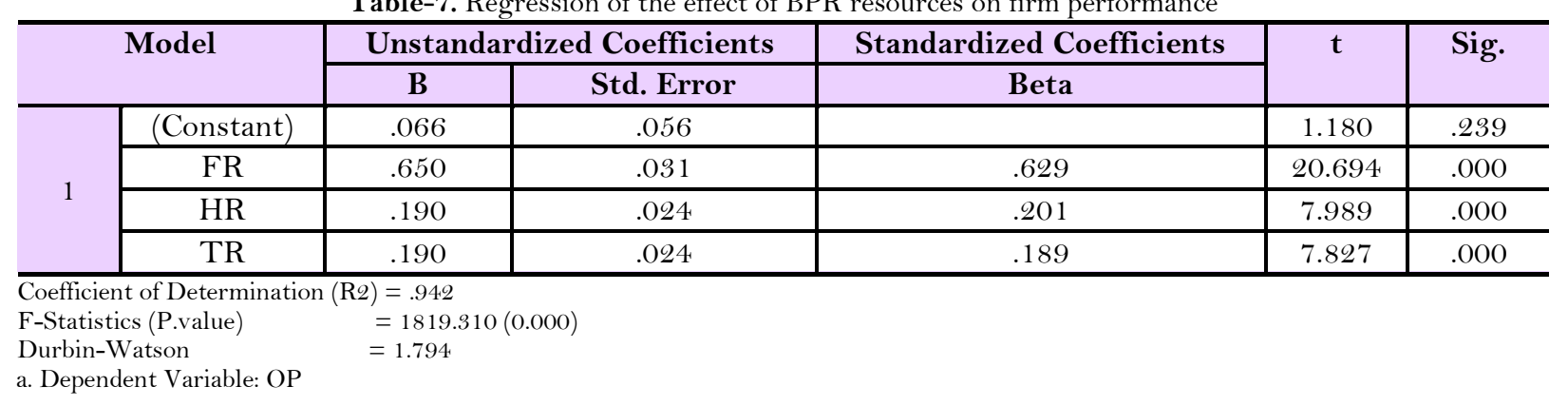

The coefficient of determination $\left(\mathrm{R}^{2}\right)$ used to test the explanatory power of the model gave a value of 0.942 . This indicates that about $94 \%$ of changes in BPR resources can explain performance of brewing firms in Nigeria. This implies that resource are very important variables that engender performance of brewing firms in Nigeria. The value of the Durbin Watson statistics is 1.794 . Since the value is approximately 2 , it indicates that there is no autocorrelation in the model. Therefore the model has a good fit.

To answer research question one "To what extent does BPR resources influence performance of brewing firms?" the standardised coefficient of regression (Beta) was used. The coefficients for financial resources (FR), human resources (HR) and technological resources (TR) are 0.629, 0.201 and 0.189 respectively. The results indicate a positive influence to the tune of $63 \%$ from financial resources and $20 \%$ from human and $19 \%$ from technological resources. It suggests that financial resource $(63 \%)$ has more influence followed by human resource $(20 \%)$ and then technological resource $(19 \%)$. The result of the t-statistics determines the significance of the coefficients. The p-values for FR, HR and TR are all less than $0.05(\mathrm{p}<0.05)$, thus all the variables have significant effect on firm performance.

To test hypothesis one: BPR resources have no significant effect on the performance of brewing firms in Nigeria. The result from F-statistics has p.value of 0.000 (p. < 0.05). Since the p-value is less than 0.05, we reject the null hypothesis and thus conclude that BPR resources have significant effect on the performance of brewing firms.

\section{Conclusion}

BPR resources had 94\% significant effect on performance in brewing firms in Nigeria. Specifically, a positive influence was established such that financial resources (63\%) has more influence followed by human resources $(20 \%)$ and then technological $(19 \%)$. This implies that the use of resources is a veritable strategy to enhancing firm performance. These results are in line with most of the related literature reviewed under BPR resource perspective. The results supports the theory of Resource Base View (RBV). It is noteworthy that finance is more important to firms than human and technological resources. This may flow from the fact that money can enhance the deployment of the other uses (human and technological). Hence, Business Process Re-engineering has become a veritable tool for enhancing resource building that can be used to enhance organisational performance (Peteraf and Barney, 2003; Dzhumalieva and Helfert, 2008).

On the overall, the study posits that the use of BPR resources is a veritable strategy to enhancing firm performance. Firms that follow the present wave of technological innovations will enhance their competiveness and survival rate. BPR is a veritable tool to enhancing employee satisfaction, team work and cooperation, quality of service delivery as well as the attainment/achievement of organizational strategic goals.

\section{Recommendations}

As adequate use of resources can lead to improved performance in brewing firms, it is therefore recommended that firms in the brewing industry and other allied manufacturing firms should employ their resources in an adequately proportionate manner. Policies that enhance good use of firms' resources are necessary in corporate organisations that aim to improve its performance. Good corporate governance is germane to organisational focus and improved performance.

\section{References}

Adeyemi, S. and M.A. Aremu, 2008. Impact assessment of business process reengineering on organizational performance. European Journal of Social Sciences, 7(1): 115-125. View at Google Scholar

Ahadi, H., 2004. Examination of the role of organizational enablers in business process reengineering and the impact of information technology. Information Resources Management Journal, 17(4): 1-19. View at Google Scholar | View at Publisher

Ahmad, H., A. Francis and M. Zairi, 2007. Business process reengineering: Critical success factors in higher education. Business Process Management Journal, 13(3): 45 1-469. View at Google Scholar |View at Publisher

Albadvi, A., A. Keramati and J. Razmi, 2007. Assessing the impact of information technology on firm performance considering the role of intervening variables: Organizational infrastructures and business processes reengineering. International Journal of Production Research, 45(12): 2697-2734. View at Google Scholar | View at Publisher

Banham, H., 2010. External environmental analysis for small and medium enterprises (SMEs). Journal of Business \& Economics Research, 8(10): 19-26. View at Google Scholar | View at Publisher

Cortina, J.M., 1993. An examination of theory and applications. Journal of Applied Psychology, 78(1): 98-104. View at Google Scholar

Devaraj, S. and R. Kohli, 2000. Information technology payoff in the health-care industry: A longitudinal study. Journal of Management Information Systems, 16(4): 41-67. View at Google Scholar |View at Publisher 
Do Carmo, C.M., V.C.K. Guimaraes and T. Guimaraes, 2005. Empirically testing determinants of hospital BPR success. International Journal of Health Care Quality Assurance, 18(7): 552-563. View at Google Scholar $\mid$ View at Publisher

Dzhumalieva, S. and M. Helfert, 2008. Conceptual framework for handling complex administrative processes in E-government, Austria. International United Information Systems Conference, 2(22-25).

Gail, M.S. and A.R. Artino, 2013. Analyzing and interpreting data from likert-type scales. Journal of Graduate Medical Education, 5(4): 541542. View at Google Scholar $\mid$ View at Publisher

Guba, E.G. and Y.S. Lincoln, 2005. Paradigmatic controversies, contradictions, and emerging confluences. 3rd Edn., Oaks: Sage Handbook of Qualitative Research, Sage Publications. pp: 191-216.

Hesson, M., 2007. Business process reengineering in UAE public sector: A naturalization and residency case study. Business Process Management Journal, 13(5): 707-727. View at Google Scholar | View at Publisher

Idris, F., 2011. Total quality management (TQM) and sustainable company performances: Examining the relationship in Malaysian firms. International Journal of Bossiness and Society, 12(1): 31-52. View at Google Scholar

Kassahun, A.E., 2012. The effect of business process reengineering on public sector organisation performance (a developing economy context). A Thesis Submitted for the Degree of Doctor of Philosophy. School of Business Information Technology and Logistics Business College, RMIT University.

Khong, K.W. and S. Richardson, 2003. Business process reengineering and managing service quality in banks and finance companies, Malaysian. Journal of Business Management, 13(1): 54-71. View at Google Scholar | View at Publisher

Macintosh, R., 2003. BPR: Alive and well in the public sector. International Journal of Operations \& Production Management, 23(3): 327344. View at Google Scholar | View at Publisher

McAdam, R. and M. Corrigan, 2001. Re-engineering in public sector health care: A telecommunications case study. International Journal of Health Care Quality Assurance, 14(5): 218-227. View at Google Scholar | View at Publisher

Mouzas, S., 2006. Efficiency versus effectiveness in business networks. Journal of Business Research, 59(10): 1124-1132. View at Google Scholar View at Publisher

Nadeem, M. and R. Ahmad, 2016. Impact of business process reengineering on the performance of banks in Pakistan. Business and Economics Journal, 7(1): 1 - 3. View at Google Scholar |View at Publisher

Nunally, J.C., 1978. Psychometric theory. 2nd Edn., New York: McGraw Hill.

Nworgu, B.G., 2006. Educational research: Basic issues and methodology. Owerri: Wisdom Publishers.

Ogbo, A.I., E.Y. Attah, U.J.F. Ewurum and C.O. Ugbam, 2015. Business process reengineering and performance of commercial banks in North Central Nigeria. International Journal of Contemporary Applied Sciences, 2(10): 1 - 13. View at Google Scholar

Ongaro, E., 2004. Process management in the public sector: The experience of one-stop shops in Italy. International Journal of Public Sector Management, 17(1): $81-107$. View at Google Scholar | View at Publisher

Orogbu, O.L., C.U. Onyeizugbe and N.F. Onuzulike, 2015. Business process reengineering and organizational performance of selected automobile firms in Southeast of Nigeria. European Journal of Business, Economics and Accountancy, 3(5): 2056-6018. View at Google Scholar

Peteraf, M. and J. Barney, 2003. Unraveling the resource-based tangle. Managerial and Decision Economics, 24(4): 309-323. View at Google Scholar | View at Publisher

Ranjit, 2006. Multicollinearity: Causes, effects and remedies. New Delhi: IASRI.

Rigby, D.K., 2015. Management tools 2015: An executive's guide. Boston: Bain \& Company, Inc.

Ringim, K.J., M.R. Razalli and N. Hasnan, 2012. Moderating effect of information technology (IT) capability on the business process reengineering factors and organizational performance of bank. African Journal of Business Management, 6(16): 5551-5567. View at Google Scholar

Scholl, H.J., 2005. E-government-induced business process change (BPC): An empirical study of current practices. International Journal of Electronic Government Research, 1(2): 27-49. View at Google Scholar $\mid$ View at Publisher

Sentanin, F., F. Santos and J. Jabbour, 2008. Business process management in a Brazilian public research centre. Business Process Management Journal, 14(4): 483-496. View at Google Scholar | View at Publisher

Sharma, M., 2006. Business process reengineering: A tool to further bank strategic goals. Journal of Management Information Systems, 12(1): $65-74$. View at Google Scholar

Sung, T.K. and D.V. Gibson, 1998. Critical success factors for business reengineering and corporate performance: The case of Korean corporations. Technological Forecasting and Social Change, 58(3): 297-311. View at Google Scholar | View at Publisher

Thong, J., C. Yap and K. Seah, 2000. Business process reengineering in the public sector: The case of the housing development board in Singapore. Journal of Management Information Systems, 17(1): 245-270. View at Google Scholar | View at Publisher

Weerakkody, V., M. Janssen and Y.K. Dwivedi, 2011. Transformational change and business process reengineering (BPR): Lessons from the British and Dutch Public Sector. Government Information Quarterly, 28(3): 320-328. View at Google Scholar |View at Publisher

Willcocks, L.P., 2002. How radical was IT-enabled BPR? Evidence on financial and business impacts. International Journal of Flexible Manufacturing Systems, 14(1): 11-31. View at Google Scholar

Zigiaris, S., 2000. Business process re-engineering. Report Produced for the EC Funded Project. INNOREGIO: Dissemination of Innovation and Knowledge Management Techniques.

Citation | Akam, G. U.; Okeke, M. N.; Kekeocha, M. E.; Onuorah,
A. N. (2018). Business Process Reengineering Resources and the Performance of Quoted Brewing Firms in Nigeria. Asian Business Research Journal, 3: 15-25.

History:

Received: 29 May 2018

Revised: 9 August 2018

Accepted: 28 August 2018

Accepted: 28 August 2018
Published: 5 September 2018

Licensed: This work is licensed under a Creative Commons

Attribution 3.0 License (oc)

Publisher: Eastern Centre of Science and Education

Eastern Centre of Science and Education is not responsible or answerable for any loss, damage or liability, etc. caused in relation to/arising out of the use of the content. Any queries should be directed to the corresponding author of the article.
Acknowledgement: All authors contributed to the conception and design of the study.

Funding: This study received no specific financial support.

Competing Interests: The authors declare that they have no conflict of interests.

Transparency: The authors confirm that the manuscript is an honest, accurate, and transparent account of the study was reported; that no vital features of the study have been omitted; and that any discrepancies from the study as planned have been explained.

Ethical: This study follows all ethical practices during writing. 